\title{
Poszukiwanie źródeł odporności na stresy biotyczne w dawnych odmianach i populacjach miejscowych pszenic i pszenżyta
}

\author{
The search for sources of biotic stress resistance in old varieties and landraces \\ of wheat and triticale
}

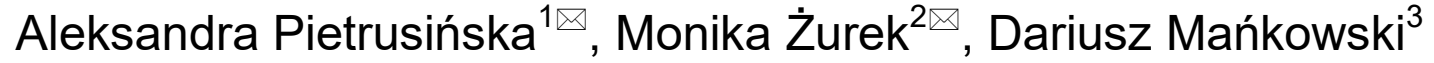 \\ ${ }^{1}$ Krajowe Centrum Roślinnych Zasobów Genowych Pracownia Gromadzenia i Oceny Roślin, Instytut Hodowli i \\ Aklimatyzacji Roślin — Państwowy Instytut Badawczy, Radzików, 05-870 Błonie, Polska \\ ${ }^{2}$ Zakład Genetyki i Hodowli Roślin, Pracownia Kukurydzy i Pszenżyta Instytut Hodowli i Aklimatyzacji Roślin — \\ Państwowy Instytut Badawczy, Radzików, 05-870 Błonie, Polska \\ ${ }^{3}$ Zakład Nasiennictwa i Nasionoznawstwa, Pracownia Ekonomiki Nasiennictwa i Hodowli Roślin, Instytut Hodowli \\ i Aklimatyzacji Roślin — Państwowy Instytut Badawczy, Radzików, 05-870 Błonie, Polska \\ $\triangle$ e-mail: a.pietrusinska@ihar.edu.pl,m.zurek@ihar.edu.pl
}

\begin{abstract}
Sprostanie wzrastającemu popytowi na zboża wymaga wyhodowania odmian wysoko plonujących, odpornych na wzrastającą presję ze strony czynników stresowych. Zubożenie puli genowej nowoczesnych odmian zbóż spowodowało zwrócenie zainteresowania naukowców i hodowców na inne potencjalne źródła genów odporności. Dawne odmiany oraz populacje miejscowe zbóż są jednym z perspektywicznych źródeł pozyskiwania genów odporności. Charakteryzują się one dużą różnorodnością morfologiczną, użytkową i genetyczną. Celem przedstawionych prac była charakterystyka pod kątem możliwości pozyskania z dawnych odmianach i populacji miejscowych, efektywnych i trwałych źródeł odporności na mączniaka prawdziwego zbóż i traw. Przy wykorzystaniu selekcji fenotypowej wytypowano obiekty charakteryzujące się reakcją wrażliwości lub odporności na zastosowane izolaty różnicujące $\mathrm{z}$ różnych regionów kraju. W celu opisania zróżnicowania pomiędzy badanymi liniami / odmianami oraz izolatami mączniaka prawdziwego przeprowadzono analizy statystyczne.
\end{abstract}

Słowa kluczowe: dawne odmiany, geny odporności, hodowla odpornościowa, odmiany miejscowe, różnorodność genetyczna, źródła odporności

\begin{abstract}
Meeting growing demand for grain requires growing high-yielding varieties that are resistant to increasing pressure from stress factors. The depletion of the gene pool of modern cereal varieties resulted in the scientists and breeders being attracted to other potential sources of resistance genes. Old varieties and local populations of cereals are one of the prospective sources of acquiring resistance genes. They are characterized by a large morphological, utilitarian and genetic diversity. The purpose of the presented works was to characterize the possibility of obtaining from local varieties and populations of local, effective and lasting sources of resistance to powdery mildew of real cereals and grasses. Using the phenotypic selection, objects characterized by a sensitivity or resistance reaction to the applied isolating isolates from different regions of the country were selected. In order to describe the differences between the examined lines / strains and the isolates of powdery mildew, statistical analyzes were carried out.
\end{abstract}

Key words: old varieties, resistance genes, resistance breeding, landraces, genetic diversity, sources of resistance

\section{Wstęp}

Postępujące zmiany klimatyczne wpływają na wzrost presji ze strony czynników biotycznych i abiotycznych, na rośliny uprawne. W Polsce obserwuje się tendencję wzrostową w udziale zbóż w ogólnym areale zasiewów. Według danych GUS w 2018 roku areał zasiewów zbóż wyniósł $74 \%$ wszystkich upraw. Systematycznie wzrasta również zapotrzebowanie na ziarno zbóż. Według danych szacunkowych wzrośnie ono o $70 \%$ do 2050 roku. Osiągnięcie tego poziomu wymaga podwojenia plonów. Sprostanie wzrastającemu popytowi na zboża wymaga wyhodowania odmian wysoko plonujących, odpornych na wzrastającą presję ze strony czynników stresowych. Zubożenie puli genowej nowoczesnych odmian zbóż spowodowało zwrócenie zainteresowania naukowców i hodowców na inne potencjalne źródła genów odporności (Feuillet i in., 2007; Hajjar i in., 2007). Taką pulę zasobów stanowią odmiany dawne oraz populacje miejscowe. $Z$ uwagi na strategiczne, z punktu widzenia bezpieczeństwa żywnościowego, znaczenie roślin zbożowych, intensywnie poszukiwane są efektywne źródła wnoszące cechę odporności na ważne gospodarczo choroby zbóż. Najważniejsze $\mathrm{z}$ nich to rdza brunatna oraz mączniak prawdziwy zbóż i traw (Jańczak i Pawlak, 2006). Choroby te występują na terenie całego kraju każdego roku, w zmiennym nasileniu, zależnym od 
warunków pogodowych (Kryczyński i Weber, 2011). Odmiany pszenicy, pszenżyta oraz jęczmienia dopuszczone do uprawy w Polsce oraz nowe, będące $w$ badaniach rejestrowych, pod względem odporności na porażanie przez grzyby Blumeria graminis i Puccinia recondita, oceniane są jako średnio podatne i podatne $\mathrm{w}$ stadium siewek, a w warunkach polowych, wrażliwe lub bardzo wrażliwe. Porażenie przez te patogeny prowadzi do znacznego spadku wielkości i jakości plonów.

Dawne odmiany oraz populacje miejscowe zbóż są jednym z perspektywicznych źródeł pozyskiwania genów odporności. Charakteryzują się one dużą różnorodnością morfologiczną, użytkową i genetyczną (Haussmann i in., 2004). Są to heterogeniczne, dynamiczne populacje, wykształcone w wyniku naturalnej presji selekcyjnej. Ponadto, ich długotrwała koewolucja $\mathrm{z}$ patogenami o różnej wirulencji spowodowała nagromadzenia alleli odporności, które mogą być cennym źródłem odporności na choroby grzybowe przy jednoczesnych małych wymaganiach glebowych.

Celem przedstawionych prac była charakterystyka pod kątem możliwości pozyskania $\mathrm{z}$ dawnych odmianach i populacji miejscowych, efektywnych i trwałych źródeł odporności na mączniaka prawdziwego zbóż i traw. Przy wykorzystaniu selekcji fenotypowej wytypowano obiekty charakteryzujące się reakcją wrażliwości lub odporności na zastosowane izolaty różnicujące $\mathrm{z}$ różnych regionów kraju. W celu opisania zróżnicowania pomiędzy badanymi liniami / odmianami oraz izolatami mączniaka prawdziwego przeprowadzono analizy statystyczne.

\section{Material i metody}

W badaniach dotyczących pszenicy wykorzystano łącznie 89 odmian oraz linii pszenicy ozimej oraz jarej, w tym: 50 dawnych odmian o nieznanym profilu odpornościowym, 15 linii/odmian testowych o znanych genach odporności na mączniaka prawdziwego zbóż i traw (geny Pm), 1 wzorzec podatnościodmiana Nimbus, 23 odmian pszenicy aktualnie uprawiane. Do oceny odporności wykorzystano łącznie 23 izolaty różnicujące pochodzące $\mathrm{z}$ różnych części kraju. W badaniach nad pszenżytem wykorzystano łącznie 154 odmian oraz linii pszenżyta ozimego oraz jarego, w tym: 138 odmian o nieznanym profilu odpornościowym, 15 linii/odmian testowych o znanych genach odporności na mączniaka prawdziwego zbóż i traw (geny $P m$ ), 1 wzorzec podatności - odmiana Marko. Do oceny odporności użyto 14 izolatów różnicujących. Doświadczenia przeprowadzono w dwóch powtórzeniach. Doświadczenie fitopatologiczne prowadzono w komorze fitotronowej (16 godz. światła / 8 godz. ciemności, temp. $16-22^{\circ} \mathrm{C}$ ). Przeprowadzono inokulację roślin izolatami $B$. graminis. Izolat różnicujący namnożono na roślinach podatnych odmian Nimbus/Marko (odmiany kontrolne), a następnie zakażono materiał roślinny poprzez równomierne strząsanie zarodników konidialnych z odmian wzorcowych. Po upływie 810 dni oceniono reakcję roślin wykorzystując pięciostopniową skalę wg Mainsa i Daetza (1930) dla mączniaka prawdziwego, w której: $0=$ brak widocznych objawów porażenia; 1 = niewielkie nekrozy; 2 = powiększające się nekrozy wraz ze skąpym zarodnikowaniem; 3 = chlorozy, grzybnia rozwinięta, lecz słabo zarodnikująca; $4=$ dobrze rozwinięta grzybnia i zarodnikująca grzybnia. Odmiany - linie o reakcji 0-2, tworzyły grupę roślin odpornych, natomiast o reakcji 3-4 grupę roślin podatnych.

\section{Wyniki i wnioski}

1. Wyodrębniono 3 grupy odmian / linii pszenicy oraz pszenżyta charakteryzujące się: całkowitą wrażliwością oraz odpornością i częściową odpornością na zastosowane izolaty różnicujące Blumeria graminis (Rys. 1; pszenica, Rys. 2 pszenżyto).

2. Wszystkie dawne odmiany / linie pszenicy porażone były przez izolaty $B$. graminis.

3. Wyodrębniono różne rasy fizjologiczne (patotypy) patogena, występujące $\mathrm{w}$ tych samych lokalizacjach na przełomie kilku lat zarówno dla pszenicy jaki i pszenżyta (Tab. 1 do Tab. 6).

4. Na podstawie uzyskanych wyników można wyselekcjonować odmiany pszenicy oraz pszenżyta, które można będzie wprowadzić do uprawy w rejonie którym nie istnieje obecnie rasa patogena, która mogłaby ją porazić.

5. Odmiany pszenżyta: Strzelce (STH) Alekto, LAD794 Fidelio, Meloman, Festino, Octavio, Orinoko; Bąków (BAH): Atletico, Wiarus, Tomko.

6. Odmiana pszenicy: Nagradowice (NAH) - Sonara, Chul $(P m 3 b)$. 


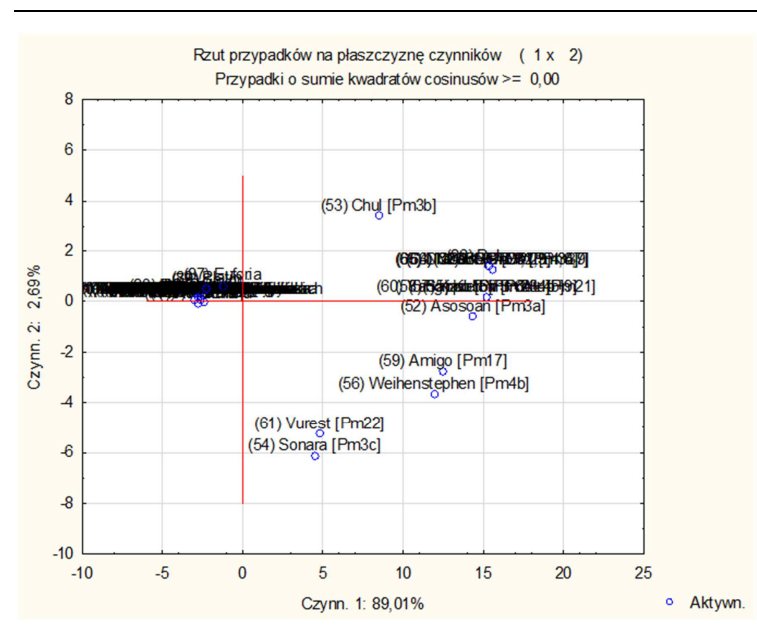

Rys. 1. Analiza głównych składowych dla 89 odmian oraz linii pszenicy

Fig.1. Principal component analysis for 89 wheat lines and cultivars

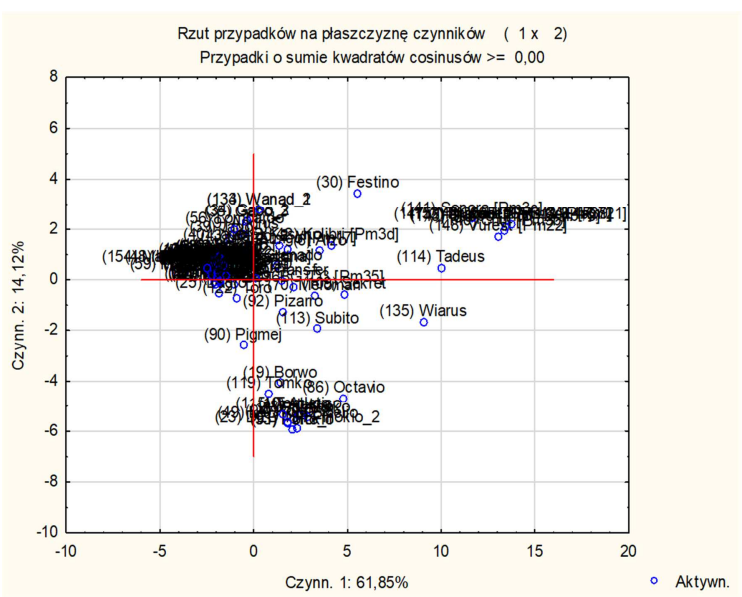

Rys. 2. Analiza głównych składowych dla 154 odmian oraz linii pszenżyta

Fig. 2. Principal component analysis for 154 triticale lines and cultivars

Tabela 1

Podsumowanie analizy wariancji dla linii pszenicy z HR Strzelce

Summary of the variance analysis for the wheat lines from Strzelce HR

\begin{tabular}{|c|c|c|c|c|c|c|}
\hline \multicolumn{7}{|c|}{ 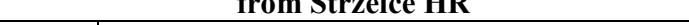 } \\
\hline \multirow[b]{2}{*}{$\begin{array}{l}\text { Grupa } \\
\text { Group }\end{array}$} & \multicolumn{6}{|c|}{ HR Strzelce } \\
\hline & $\begin{array}{l}\text { izolat } \\
\text { isolate }\end{array}$ & $\begin{array}{l}\text { średnia } \\
\text { average }\end{array}$ & 1 & 2 & 3 & 4 \\
\hline 5 & $41 \mathrm{STH}$ & 3,303371 & & $\mathrm{D}$ & & \\
\hline 1 & 6STH & 3,325843 & & & $\mathrm{C}$ & \\
\hline 6 & $58 \mathrm{STH}$ & 3,370787 & B & & & \\
\hline 4 & $21 \mathrm{STH}$ & 3,370787 & B & & & \\
\hline 3 & $8 \mathrm{STH}$ & 3,382022 & B & & & \\
\hline 2 & $7 \mathrm{STH}$ & 3,415730 & & & & $\mathrm{~A}$ \\
\hline
\end{tabular}

Tabela 2

Podsumowanie analizy wariancji dla linii pszenicy $z$ PHR, stacja Nagradowice

Summary of the variance analysis for the wheat lines from station Nagradowice of PHR

\begin{tabular}{c|c|c|c|c}
\multicolumn{5}{c}{ from station Nagradowice of PHR } \\
\hline \multirow{2}{*}{$\begin{array}{c}\text { Grupa } \\
\text { Group }\end{array}$} & \multicolumn{4}{|c}{$\begin{array}{c}\text { PHR, Stacja Nagradowice } \\
\text { Station Nagradowice of PHR }\end{array}$} \\
\cline { 2 - 5 } & $\begin{array}{c}\text { izolat } \\
\text { isolate }\end{array}$ & $\begin{array}{c}\text { średnia } \\
\text { average }\end{array}$ & 1 & 2 \\
\hline 6 & $30 \mathrm{NAH}$ & 3,235955 & $\mathrm{~B}$ & \\
5 & $29 \mathrm{NAH}$ & 3,325843 & $\mathrm{~B}$ & $\mathrm{~A}$ \\
4 & $24 \mathrm{NAH}$ & 3,325843 & $\mathrm{~B}$ & $\mathrm{~A}$ \\
1 & $3 \mathrm{NAH}$ & 3,325843 & $\mathrm{~B}$ & $\mathrm{~A}$ \\
3 & 7NAH & 3,337079 & $\mathrm{~B}$ & $\mathrm{~A}$ \\
2 & 5NAH & 3,415730 & & $\mathrm{~A}$ \\
\hline
\end{tabular}

Tabela 3

Podsumowanie analizy wariancji dla linii pszenicy $z$ HR Smolice

Summary of the variance analysis for the wheat lines from HR Smolice

\begin{tabular}{c|c|c|c|c|c}
\hline \multirow{2}{*}{$\begin{array}{c}\text { Grupa } \\
\text { Group }\end{array}$} & \multicolumn{5}{|c|}{ HR Smolice } \\
\cline { 2 - 6 } & $\begin{array}{c}\text { izolat } \\
\text { isolate }\end{array}$ & $\begin{array}{c}\text { średnia } \\
\text { average }\end{array}$ & 1 & 2 & 3 \\
\hline 6 & $28 \mathrm{SMH}$ & 3,292135 & $\mathrm{C}$ & & \\
1 & $2 \mathrm{SMH}$ & 3,303371 & $\mathrm{C}$ & & \\
3 & $13 \mathrm{SMH}$ & 3,325843 & $\mathrm{C}$ & & \\
2 & $7 \mathrm{SMH}$ & 3,370787 & & $\mathrm{~B}$ & \\
4 & $18 \mathrm{SMH}$ & 3,393258 & & $\mathrm{~B}$ & \\
5 & $25 \mathrm{SMH}$ & 3,505618 & & & $\mathrm{~A}$ \\
\hline
\end{tabular}

Tabela 4

Podsumowanie analizy wariancji dla linii pszenicy z MHR stacja Polanowice

Summary of the variance analysis for the wheat lines from Station Polanowice of MHR

\begin{tabular}{c|c|c|c|c|c}
\hline \multirow{2}{*}{$\begin{array}{c}\text { Grupa } \\
\text { Group }\end{array}$} & \multicolumn{5}{|c}{ MHR stacja Polanowice } \\
\cline { 2 - 6 } & $\begin{array}{c}\text { izolat } \\
\text { isolate }\end{array}$ & $\begin{array}{c}\text { średnia } \\
\text { average }\end{array}$ & 1 & 2 & 3 \\
\hline 4 & $18 \mathrm{POH}$ & 3,243446 & & $\mathrm{C}$ & \\
5 & $19 \mathrm{POH}$ & 3,325843 & $\mathrm{~B}$ & $\mathrm{C}$ & \\
1 & $1 \mathrm{POH}$ & 3,393258 & $\mathrm{~B}$ & & \\
3 & $10 \mathrm{POH}$ & 3,460674 & $\mathrm{~B}$ & & $\mathrm{~A}$ \\
2 & $3 \mathrm{POH}$ & 3,528090 & & $\mathrm{~A}$ \\
\hline
\end{tabular}

Tabela 5

Podsumowanie analizy wariancji dla linii pszenżyta z HR Strzelce

Summary of the variance analysis for the triticale lines from HR Strzelce

\begin{tabular}{c|l|l|l|l|l|l}
\hline \multirow{2}{*}{$\begin{array}{c}\text { Grupa } \\
\text { Group }\end{array}$} & $\begin{array}{l}\text { Izolat } \\
\text { Isolate }\end{array}$ & $\begin{array}{l}\text { Średnia } \\
\text { Average }\end{array}$ & 1 & 2 & 3 & 4 \\
\hline 6 & 4 STH & 3,163934 & & D & \\
4 & 2 STH & 3,184211 & & & D & C \\
5 & 3 STH & 3,289902 & & & D & C \\
7 & 5 STH & 3,297030 & & & & C \\
8 & $6 \mathrm{STH}$ & 3,435065 & B & & & \\
1 & 10 STH & 3,480132 & B & A & & \\
10 & 9 STH & 3,528239 & B & A & & \\
2 & $11 \mathrm{STH}$ & 3,536913 & B & A & & \\
3 & $1 \mathrm{STH}$ & 3,561056 & B & A & \\
9 & $7 \mathrm{STH}$ & 3,600000 & & $\mathrm{~A}$ & \\
\hline
\end{tabular}




\begin{tabular}{|c|c|c|c|c|c|}
\hline \multicolumn{6}{|c|}{$\begin{array}{l}\text { Tabela } 6 \\
\text { Podsumowanie analizy wariancji dla linii pszenżyta } \\
\text { z HR Smolice stacja Bąków } \\
\text { Summary of the variance analysis for the triticale lines } \\
\text { from Station Baków of HR Smolice }\end{array}$} \\
\hline \multirow[b]{2}{*}{$\begin{array}{l}\text { Grupa } \\
\text { Group }\end{array}$} & \multicolumn{5}{|c|}{$\begin{array}{l}\text { HR Smolice stacja Bạków } \\
\text { Station Bąków of HR Smolice }\end{array}$} \\
\hline & $\begin{array}{l}\text { izolat } \\
\text { isolate }\end{array}$ & $\begin{array}{r}\text { średnia } \\
\text { average }\end{array}$ & 1 & 2 & 3 \\
\hline 1 & $15 \mathrm{BAH}$ & 3,032468 & $\mathrm{C}$ & & \\
\hline 2 & 4BAH & 3,261438 & & & \\
\hline 3 & $7 \mathrm{BAH}$ & 3,527869 & & & A \\
\hline
\end{tabular}

\section{Literatura}

Feuillet C., Langridge P., Waugh R. 2007. Cereal breeding takes a walk on the wild side. Trends Genet. 24: 24 -32 .
Hajjar R., Hodgkin T. 2007. The use of wild relatives in crop improvement: a survey of developments over the last 20 years. Euphytica 156: $1-13$.

Haussmann B. I. G., Parzies H. K., Presterl T., Miedaner T. 2004. Plant genetic resources in crop improvement. Plant Genet. Resour-C. 2 (1): $3-21$.

Jańczak C., Pawlak A., 2006. Występowanie i szkodliwość mączniaka prawdziwego (Blumeria graminis) w pszenicy ozimej w latach 2003-2005. Postępy w Ochronie Roślin 46 (2): 582 - 542.

Kryczyński S., Weber Z. 2011. Fitopatologia. Tom 2. Choroby roślin uprawnych. Poznań: PWRiL, 2011, str. 350-352. ISBN 978-83-09-01077-7.

Mains E. B., Dietz S. M. 1930. Physiologic forms of barley mildew, Erysiphe graminis hordei Marchal. Phytopathol. 20: $229-239$. 